\title{
Edukasi dan pendampingan kader tentang manajemen diri lansia dengan komorbid diabetes melitus pada era pandemi covid-19 di Kelurahan Sidanegara Kabupaten Cilacap
}

\author{
Dewi Prasetyani ${ }^{*}$; Yuni Sapto Edhy Rahay ${ }^{2}$ \\ $\left.{ }^{*}\right), 2$ STIKES Al-Irsyad Al-Islamiyyah Cilacap \\ Email: prasetyanidewi78@gmail.com
}

\begin{abstract}
Abstrak: Pasien Covid-19 dengan diabetes memiliki tingkat kematian yang tinggi, yaitu 7,8\% dibandingkan pasien Covid-19 non diabetes. Puskesmas Cilacap Tengah 1 memiliki jumlah pasien diabetes terbanyak di Kabupaten Cilacap. Kegiatan pengabdian masyarakat ini dilakukan dalam dua tahap yaitu edukasi dan pendampingan kader posyandu lansia tentang manajemen diri lansia dengan DM. Sebagai langkah awal, penulis memberikan edukasi tentang manajemen diri DM kepada kader yang dihadiri oleh 19 orang kader perwakilan dari posyandu lansia yang ada di Kelurahan Sidanegara Kecamatan Cilacap Tengah. Hasil analisa data menunjukkan ada peningkatan pengetahuan kader tentang manajemen diri diabetes, dilihat dari nilai rata-rata pre-test 70,4 yang naik menjadi 76,5 pada nilai rata-rata post-test, dimana selisih nilai pre-test dan post-test adalah 6 poin. Kader juga mendapatkan buku manajemen diri DM sebagai buku pedoman. Sedangkan kegiatan pendampingan kader di posyandu lansia masih menunggu ijin dari pemerintah daerah Cilacap, karena selama pandemi Covid-19 kegiatan posyandu masih ditutup.
\end{abstract}

Kata kunci: Diabetes Melitus, Kader Posyandu Lansia, Manajemen Diri, Covid-19

\begin{abstract}
Covid-19 patients with diabetes have a high mortality rate, which is $7,8 \%$ compared to non diabetic covid-19 patients. Central Cilacap Health Center 1 has the highest number of diabetes patients in Cilacap Regency. This community service activity is carried out in 2 stages, namely education and mentoring of elderly posyandu kader regarding elderly selfmanagement with DM. As a first step, the authors provide education about self-management of DM to kader which was attended by 19 kader from the elderly posyandu in Sidanegara Village, Cilacap Tengah District. The results of data analysis showed that there was an increase in kader's knowledge about diabetes self-management, seen from the pre-test average score 70,4 which rose to 76,5 on the average post-test score, where the difference between the pre-test and post-test scores is 6 point. Kader also receive the diabetes self-management book as a guidebook. Meanwhile, kader assistance activities at the elderly posyandu are still waiting for permission from the Cilacap regional government, because during the covid-19 pandemic, posyandu activities was still closed.
\end{abstract}

Keywords: Diabetes Melitus, Diabetes Self-Management, The Posyandu Elderly Kader

\section{Pendahuluan}

Diabetes adalah penyakit kronis yang terjadi ketika pankreas tidak cukup memproduksi insulin atau ketika tubuh tidak dapat menggunakan insulin secara efektif. Kondisi ini menyebabkan hiperglikemia, yang merupakan akibat umum diabetes yang tidak terkontrol. Hiperglikemia kronis dapat menyebabkan kerusakan serius pada berbagai system tubuh, khususnya sistem saraf dan pembuluh darah (World Health Organization, 2020). 
Diabetes adalah masalah kesehatan utama dan telah mencapai tingkat yang mengkhawatirkan. Hampir setengah milyar orang hidup dengan diabetes di seluruh dunia. Data dari International Diabetes Federation (IDF) menunjukkan bahwa pada tahun 2019 terdapat 463 milyar orang hidup dengan diabetes di seluruh dunia pada usia 20-79 tahun, diperkirakan meningkat menjadi 578 milyar pada tahun 2030 dan menjadi 700 milyar pada tahun 2045 (IDF, 2019).

Peningkatan jumlah orang dengan diabetes terjadi lebih cepat di negara-negara berpenghasilan rendah dan menengah dibandingkan negara-negara berpenghasilan tinggi. Hasil Riskesdas menunjukkan bahwa prevalensi orang dengan diabetes di Indonesia pada tahun 2018 meningkat 8,5\% atau sekitar 20,4 juta dibandingkan tahun 2013. Sedangkan di Jawa Tengah meningkat 1,5\% pada tahun 2018 dibandingkan tahun 2013 (InfoDatin, 2018). Prevalensi diabetes di Kabupaten Cilacap mengalami penurunan pada tahun 2019. Pada tahun 2014 tercatat 9.295 kasus dan pada tahun 2019 tercatat 7.840 kasus orang dengan diabetes (Data Puskesmas Cilacap Tengah 1, 2020).

Pandemi virus korona yang disebabkan oleh SARS-CoV-2 telah menginfeksi lebih dari 1 juta orang di seluruh dunia. Covid-19 menyerang hampir seluruh kalangan usia, namun data yang ada menunjukkan bahwa kelompok usia lanjut dan yang memiliki penyakit kronis (ko-morbid) beresiko terkena lebih sering dan mengalami komplikasi lebih buruk akibat penyakit ini. Diabetes merupakan komorbid kedua tersering ditemukan setelah hipertensi, yaitu $8 \%$ dari kasus dan dengan angka kematian tiga kali lipat dibandingkan pasien secara umum (Perkeni, 2020).

Penelitian yang dilakukan di Provinsi Hubei, China menunjukkan bahwa pasien Covid-19 dengan riwayat diabetes yang dirawat di RS membutuhkan lebih banyak intervensi medis. Pasien juga memiliki tingkat kematian yang tinggi, yaitu 7,8\% dibandingkan pasien Covid-19 non diabetes. Meski demikian, resiko kematian pasien cenderung lebih rendah bila kadar gula darah terkontrol. Pasien Covid-19 dengan diabetes dan kadar gula darah terkontrol cenderung membutuhkan lebih sedikit intervensi medis dan lebih sedikit mengalami komplikasi (Ramadhani, 2020)

Upaya pengendalian gula darah pada orang yang hidup dengan diabetes sangat kompleks, karena tidak hanya membutuhkan pengobatan saja, tetapi juga menuntut perubahan perilaku yang sudah melekat dalam gaya hidup sehari-hari. .Manajemen diri diabetes merupakan prosedur pengendalian kadar gula darah yang diprogramkan oleh Perkeni. Manajemen diri diabetes dibutuhkan oleh pasien diabetes karena 95\% perawatan diabetes dilakukan secara mandiri oleh pasien dan keluarganya. Terdapat lima domain manajemen diri diabetes menurut Perkeni (2018), yaitu diet, latihan jasmani, kontrol teratur, terapi farmakologi dan perawatan kaki.

Alasan dilakukannya kegiatan pengabdian ini di wilayah kerja Puskesmas Cilacap Tengah 1 adalah karena penyebaran kasus diabetes di Kabupaten Cilacap paling banyak terjadi di wilayah kerja Puskesmas Cilacap Tengah 1, yaitu 315 kasus. Kegiatan ini juga merupakan tindak lanjut dari penelitian penulis sebelumnya tentang kemampuan self-care pasien diabetes di Prolanis Puskesmas Cilacap Tengah 1, menunjukkan bahwa kemampuan manajemen diri pasiendiabetes rata-rata 3 hari yang artinya belum maksimal (Prasetyani \& Apriani, 2017). Penulis mencoba mengaplikasikan hasil penelitian kepada kader untuk meningkatkan pengetahuan kader tentang manajemen diri diabetes, sehingga diharapkan nantinya kader dapat memberikan edukasi pada lansia tentang manajemen diri diabetes. Sementara itu, berdasarkan data dari Satgas Covid-19 Kabupaten Cilacap, Kecamatan Cilacap Tengah menduduki peringkat pertama dengan angka kejadian covid-19 terbanyak. Hal ini menjadi perhatian karena kelompok lanjut usia dengan komorbid seperti diabetes beresiko lebih rentan terkena Covid-19.

\section{Metode}

Pengabdian kepada masyarakat ini dilakukan di Kelurahan Sidanegara sebagai wilayah kerja Puskesmas Cilacap Tengah 1. Sasaran kegiatan adalah kader posyandu lansia di Kelurahan Sidanegara. Tahap persiapan diawali dengan identifikasi kader posyandu lansia, surat menyurat untuk undangan 
dan peminjaman gedung pertemuan di kelurahan, penyiapan tool penyuluhan yang berisi buku panduan manajemen diri dan kuesioner,serta persiapan media untuk penyuluhan.

Peserta kegiatan sebanyak 19 orang kader posyandu lansia di kelurahan Sidanegara. Kegiatan dilaksanakan dalam satu hari dari jam 08.00 - 12.00 WIB di gedung pertemuan kelurahan Sidanegara. Adapun tahap pelaksanaannya adalah dengan pre-test, pemberian materi manajemen diri pasien diabetes dan diakhiri dengan post-test. Selanjutnya akan dilakukan kegiatan monitoring dan evaluasi dengan pendampingan kader dalam kegiatan posyandu lansia terkait manajemen diri pada lansia dengan diabetes.

\section{Hasil dan Pembahasan}

Kegiatan pengabdian masyarakat ini dilaksanakan di balai desa Kelurahan Sidanegara pada hari Selasa, 21 Juli 2020. Sebanyak 19 orang kader perwakilan dari masing-masing posyandu lansia di Kelurahan Sidanegara menghadiri kegiatan tersebut, didampingi oleh petugas Puskesmas Cilacap Tengah 1 dan perangkat desa Kelurahan Sidanegara. Kegiatan dilaksanakan dengan menerapkan protokol kesehatan untuk mencegah penularan virus Covid-19. Tempat duduk peserta dan tim pengabdian direnggangkan untuk menjaga jarak aman, baik peserta maupun tim dilakukan pemeriksaan suhu tubuh dan mencuci tangan sebelum masuk ke ruangan. Seluruh peserta kegiatan pengabdian masyarakat wajib memakai masker.

Untuk mengetahui pengetahuan kader tentang manajemen diri diabetes sebelum diberikan materi, seluruh peserta diberikan lembar pre-test. Materi diberikan setelah seluruh peserta selesai mengerjakan pre test. Pemberian materi dilakukan dalam dua tahap, yaitu materi tentang diabetes melitus dan manajemen diri diabetes melitus. Pemberian materi berlangsung melebihi waktu yang ditentukan karena peserta sangat aktif bertanya khususnya tentang pengelolaan diabetes pada pengaturan diet dan latihan jasmani. Kegiatan pengabdian masyarakat diakhiri dengan pembagian lembar post-test untuk mengetahui pemahaman kader tentang materi yang diberikan.

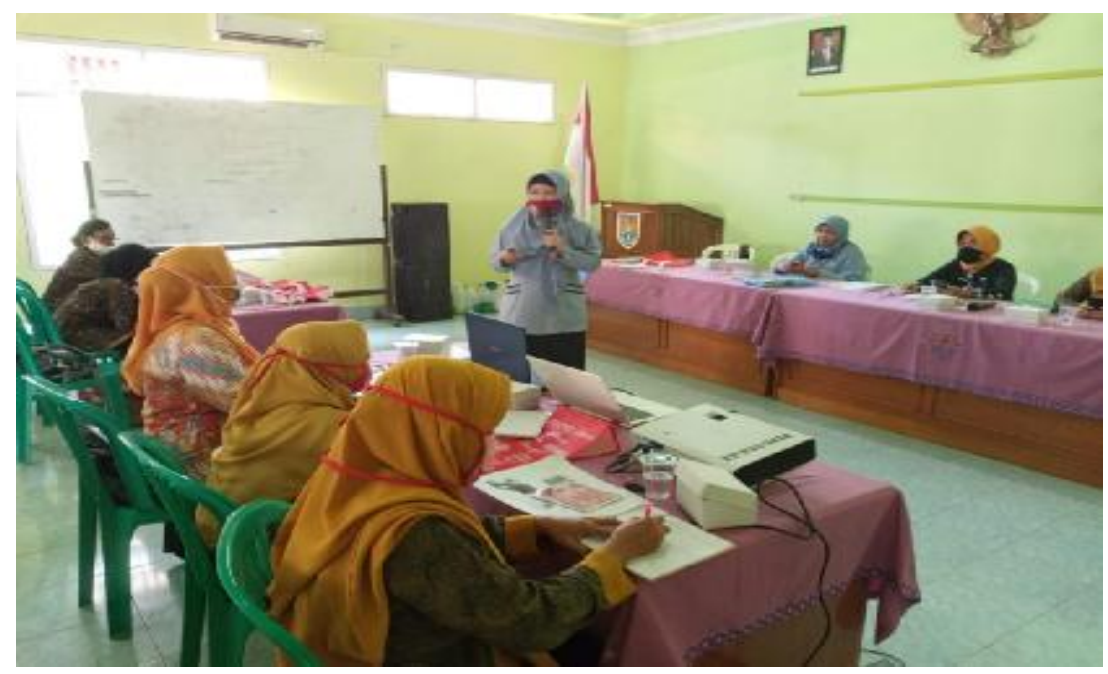

Gambar 1. Pelaksanaan penyuluhan manajemen diri diabetes pada kader posyandu lansia

Terdapat perbedaan rata-rata hasil pre-test dan post-test. Rata-rata nilai pre-test kader adalah 70,4 dan post-test 76,5. Selisih nilai pre-test dan post-test adalah 6 poin. Hal ini menunjukkan bahwa pengetahuan awal kader dalam kategori baik dan meningkat setelah mendapatkan materi tentang manajemen diri diabetes. Pengetahuan kader posyandu lansia yang baik menunjukkan bahwa kader posyandu lansia di Kelurahan Sidanegara sudah memiliki wawasan yang baik tentang diabetes dan 
pengelolaannya. Pengetahuan tersebut didapatkan kader baik secara mandiri maupun dari penyuluhan atau pelatihan yang rutin diberikan oleh pihak Puskesmas Cilacap Tengah 1. Pengetahuan kader meningkat 6 poin setelah diberikan materi. Hal ini menunjukkan bahwa pemberian materi tentang manajemen diri diabetes memberikan efek edukatif yang dapat meningkatkan pengetahuan kader.

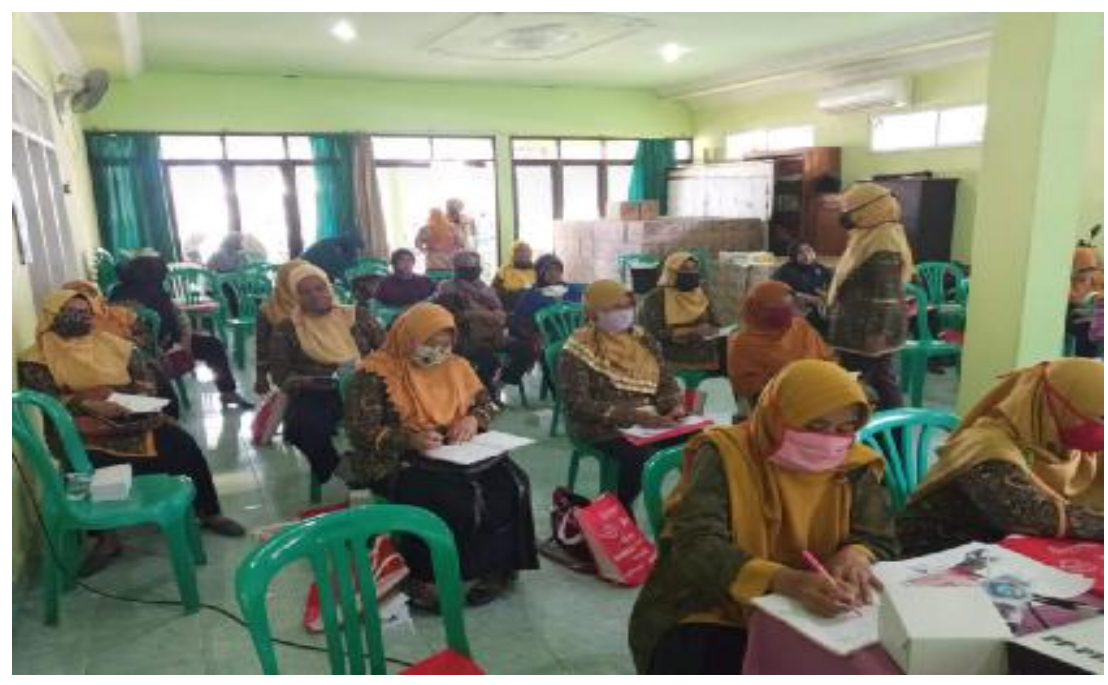

Gambar 1. Pelaksanaan penyuluhan manajemen diri diabetes pada kader posyandu lansia

Kader kesehatan adalah kelompok anggota masyarakat yang bersedia, mampu dan memiliki waktu mengabdikan diri secara sukarela di bidang kesehatan. Seorang kader harus memiliki pengetahuan yang baik tentang pengelolaan penyakit sehingga dapat menjalankan perannya sebagai pemberi promosi kesehatan maupun pemberi pertolongan dasar. Pengetahuan yang baik dapat membentuk sikap positif kader dan meningkatkan rasa percaya diri kader untuk menularkan ilmu yang telah didapat saat memberikan penyuluhan kepada masyarakat yang membutuhkan.

Tujuan dari kegiatan pengabdian masyarakat ini selain meningkatkan pengetahuan kader juga melakukan pendampingan kader untuk mengevaluasi kemampuan kader dalam mengelola lansia diabetes di posyandu lansia, kaitannya dengan manajemen diri diabetes. Pendampingan kader belum bisa terlaksana karena Kabupaten Cilacap sampai saat ini masih masuk dalam zona merah pandemic covid-19. Sehingga kegiatan posyandu sampai saat ini belum diijinkan untuk aktif kembali. Supaya ilmu yang sudah diberikan kepada kader bisa selalu diingat, maka kader dibekali buku panduan manajemen diri diabetes yang sederhana dan mudah dipahami. Pendampingan kader akan dilakukan setelah posyandu lansia aktif kembali.

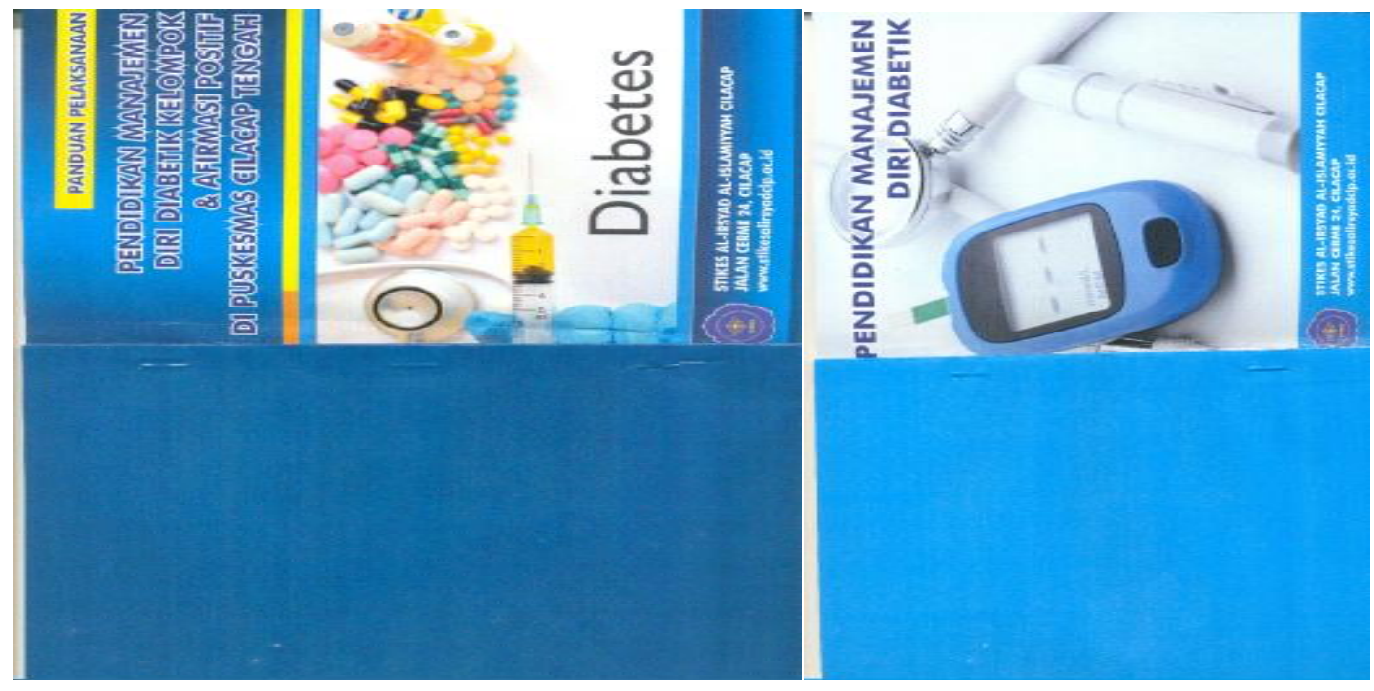

Gambar 2. Buku panduan manajemen diri diabetes melitus 


\section{Kesimpulan}

Pelaksanaan kegiatan pengabdian masyarakat berlangsung dengan baik, diikuti 19 orang kader yang dengan aktif mengikuti kegiatan hingga selesai. Pengetahuan kader meningkat ditunjukkan dari selisih rata-rata nilai pre dan post-test. Rata-rata nilai pre-test adalah 70,4 dan rata-rata post-test 76,5 dengan peningkatan 6 poin setelah diberikan edukasi tentang manajemen diri diabetes. Pendampingan kader akan dilaksanakan setelah posyandu lansia aktif kembali. Sebagai buku pegangan, kader mendapatkan buku panduan manajemen diri diabetes.

\section{Daftar Pustaka}

Chrisanto, E. Y., Rachmawati, M., \& Yulendasari, R. (2020). Penyuluhan manfaat buah naga merah dalam menurunkan kadar gula darah pada penderita diabetes melitus. Indonesia Berdaya, 1(2), 8994.

InfoDatin Pusat Data dan Informasi Kementrian Kesehatan RI. Hari Diabetes Sedunia 2018. file://K:Users/ASUS/Downloads/infodatin-Diabetes-2018.pdf. Diakses tanggal 22 Mei 2020

International Diabetes Federation. 2019. IDF Diabetes Atlas, Ninth Edition. www.diabetesatlas.org. Diakses tanggal 20 Mei 2020.

Nur, M., \& Mukhlis, H. (2020). Kualitas hidup ditinjau dari pengetahuan keluarga tentang perawatan lansia. Indonesia Berdaya, 1(1), 15-22.

Perkeni. 2019. Pedoman Pengelolaan Dan Pencegahan Diabetes Melitus Tipe 2 Dewasa Di Indonesia 2019. Penerbit PB Perkeni

Perkeni. $\quad$ https://pbperkeni.or.id/pernyataan-resmi-dan-rekomendasi-penanganan-diabetes-mellitus-di-erapandemi-covid-19/. Diakses tanggal 22 Mei 2020

Prasetyani D., Apriani, E. 2017. Pengaruh Diabetes Self-Management Education (DSME) Kelompok Ditambah Afirmasi Positif Terhadap Kemampuan Self-Care Pasien DM Tipe 2. STIKES Al Irsyad Al Islamiyyah Cilacap.

Prasetyani, D., Apriani E. September 2017. Karakteristik Pasien Diabetes Melitus Tipe 2 Di Puskesmas Cilacap Tengah 1 dan 2. Prosiding Seminar Nasional dan Hasil-Hasil Penelitian Serta Pengabdian Masyarakat di Bidang Kesehatan. AKBID YLPP Purwokerto.

Prasetyani, D., Apriani, E., Rahayu, EDH. Maret 2018. Hubungan Karakteristik Pasien Dengan Kemampuan Self-Care Pada Pasien DM Tipe 2 Di Puskesmas Cilacap Tengah 1 dan 2. Jurnal Kesehatan Al-Irsyad. Vol. IX, No. 1.

Profil Kesehatan Cilacap tahun 2014. https://pusdatin.kemkes.go.id/resources/download/profil/PROFIL_KAB_KOTA_2014/3301_Jateng_Kab_Cila cap 2014.pdf._Diakses tanggal 23 Mei 2020

Ramadhani. Kontrol Gula Jadi Kunci Penanganan Pasien Covid-19 dengan DM. https://republika.co.id/berita/q9pn21368/kontrol-gula-jadi-kunci-penanganan-pasien-covid19-dengan-dm.

Diakses tanggal 20 Mei 2020

Setiawan, H., Mukhlis, H., Wahyudi, D., \& Damayanti, R. (2020). Kualitas Hidup Ditinjau dari Tingkat Kecemasan Pasien Penderita Ulkus Diabetikum. Majalah Kesehatan Indonesia, 1(2), 33 - 38. Retrieved from https://ukinstitute.org gournals/1/makein/article/view/1207 
World Health Organization. Diabetes. https:/wwww.who.int/news-room/fact-sheets/detail/diabetes. June. Diakses tanggal 23 Mei 2020 